Research article

\title{
Undergraduate Pharmacology Written Question Papers of Different Universities of Bangladesh: Analysis of One Decade
}

Fatema Johora ${ }^{1}$, Asma Akter Abbasy ${ }^{2}$, Sabiha Mahboob ${ }^{3}$, Fatiha Tasmin Jeenia ${ }^{4}$, Jannatul Ferdoush ${ }^{5 *}$, Md Sayedur Rahman ${ }^{6}$

Author Affiliations

${ }^{1}$ Associate Professor, Department of Pharmacology \& Therapeutics, Army Medical College Bogura, Bogura

${ }^{2}$ Associate Professor, Department of Pharmacology\& Therapeutics, Brahmanbaria Medical College, Brahmanbaria

${ }^{3}$ Major Sabiha Mahboob, Medical Officer, CMH Bogura, Bogura

${ }^{4}$ Assistant professor, Department of Pharmacology\& Therapeutics, Chattogram International Medical College, Chattogram

${ }^{5}$ Associate Professor, Department of Pharmacology \& Therapeutics, BGC Trust Medical College, Chattogram

${ }^{6}$ Professor and Chairman, Department of Pharmacology, Bangabandhu Sheikh Mujib Medical University, Shahbag, Dhaka

\section{Undergraduate Pharmacology Written Question Papers of Different Universities of Bangladesh:}




\title{
Analysis of One Decade
}

\begin{abstract}
Background: It is expected that pharmacology education should prepare students as rational prescriber. Credibility of undergraduate pharmacology curricula is rather questionable in this aspect. As assessment shapes learning priorities, it is crucial to design assessment methods of pharmacology in right way to achieve the expected learning outcomes of future physicians.
\end{abstract}

Materials and Methods: This descriptive cross-sectional study was conducted to compare the reflection of curricular objectives, content coverage and national health priorities in undergraduate pharmacology written question papers (SAQ) of different universities of Bangladesh in last 10 years (January 2010 to November 2019). Total 131 question papers were collected, and reflection of curricular objectives, content coverage and selective disease burdens were evaluated and compared.

Result: One objective regarding factual knowledge (pharmacological effects, mechanisms of action, pharmacokinetic characteristics and adverse reactions of drugs) had significant higher weightage throughout the decade in all universities. There were statistically significant differences in weightage of reflection of five curricular objectives ( $\mathrm{p}$ value $<0.00001,0.001,0.003,0.004,0.02$ ) among different universities. There was not a single question reflecting the ethical and legal issues involved in drug prescribing, development, manufacture and marketing in the decade in any university. Chemotherapy was the highest covered area $(19.4 \pm 3.3)$, followed by central nervous system $(16.0 \pm 3.4)$ and general principles of pharmacology $(14.3 \pm 3.2)$ throughout the last ten years in all universities. There was statistically also significant difference among different universities in weightage of all content areas except Gastrointestinal pharmacology. Statistically significant difference ( $\mathrm{p}$ value $<0.00001$ ) among different universities in cardiovascular diseases burden was observed.

Conclusion: Current study found variation in pharmacology written question papers of different universities in the aspects of reflection of curricular objectives, content coverage and cardiovascular disease burden.

Keywords: Undergraduate pharmacology, written question papers, SAQ, analysis 


\section{INTRODUCTION}

Undergraduate pharmacology education has always been a topic of tense debate. Credibility of pharmacology education in coping pace with rapid changes and requirements of clinical practice is questionable. ${ }^{1,2}$ Studies concluded weakness in pharmacological knowledge and skill in prescribing medicines as an important factor of medication error. ${ }^{3,4,5,6}$ Medical students around the world seek more requirement of attention in their pharmacology education. ${ }^{7,8}$

Curriculum is a formal document including course content, objectives, learning outcomes, educational strategies and assessments for achievement of learning, teaching and evaluation under the guidance of educational institutions. It represents the expression of educational ideas in practices. ${ }^{9,}{ }^{10}$ In any curriculum, a close match between instructional objectives, methods and assessment procedures are required. ${ }^{11}$ It is important to assure that objectives are measurable and specific level of competence being delineated. The assessment methods measures whether the objectives are achieved or not through formative and summative examinations. ${ }^{12}$ Formative assessments provide benchmarks to orient the learner who is approaching a relatively unstructured body of knowledge. They can reinforce students' intrinsic motivation to learn and inspire them to set higher standards for themselves. ${ }^{13}$ On the other hand, summative assessments are intended to provide professional self-regulation and accountability as well as act as a barrier to further practice or training. ${ }^{14}$ All methods of assessment have strengths and intrinsic flaws. ${ }^{15}$ Written assessment has been considered as cornerstone of testing knowledge of graduates. ${ }^{16}$ Various types of questions like MCQ, SAQ, MEQ and SEQ can be used in written assessment. ${ }^{17}$ Due to limited validity, poor reliability and less objectivity, long essay questions lost popularity as instrument of written assessment. ${ }^{18,19}$ Nowadays, SAQs are widely used 
because of greater objectivity, reliability, specificity and coverage of wider areas of course content.

In Bangladesh, first documented curriculum of MBBS program was introduced in 1988. ${ }^{20}$ After extensive review a revised curriculum was implemented on students of 2002-2003 session. Introduction of SAQ and MCQ in written assessment system instead of essay questions were the dramatic changes observed in that curriculum. ${ }^{21}$ Later, reviewed MBBS curriculum 2012 has been developed, and implemented from session 2012-13. ${ }^{22}$ Seven public universities, Bangladesh University of Professionals (BUP), University of Dhaka (DU), University of Chittagong (CU), University of Rajshahi (RU), Shahjalal University of Science and Technology (SUST), University of Science and Technology, Chittagong (USTC) and Gono Bishwabidyalay (GB) are conducting MBBS examination of all medical students under the guidance of Bangladesh Medical \& Dental Council (BMDC). After the implementation of curriculum 2002, Pharmacology had been assessed in 2nd professional exam since January, 2007 and in curriculum 2012, it has been assessed in 3rd professional exam since May, 2017. Several studies were done to evaluate Pharmacology curriculum, textbooks and question papers through different perspectives. ${ }^{23-28}$ In this background, current study was conducted to evaluate Pharmacology written question papers of different universities over last 10 years in the context of reflection of curricular objectives, content coverage and selective disease burdens. 


\section{MATERIALS \& METHODS}

The objectives of this study were to compare the reflection of curricular objectives, content coverage and national health priorities in undergraduate pharmacology written question papers of different universities of Bangladesh.

\section{Study Design and Procedure}

This descriptive cross-sectional study was conducted from January 2021 to June 2021. After obtaining ethical approval from the Institutional Review Board (IRB) of Combined Military Hospital (CMH) Bogura, researchers collected pharmacology written question papers (SAQ) of last 10 years (January 2010 to November 2019) of all 7 universities offering MBBS degree (Bangladesh University of Professionals, University of Dhaka, University of Chittagong, University of Rajshahi, Shahjalal University of Science and Technology, University of Science and Technology, Chittagong and Gono Bishwabidyalay). Total 131 question papers were collected and reviewed to meet the study objective.

Both curriculum 2002 and 2012 clearly described learning objectives for undergraduate pharmacology education. There were 10 curricular objectives in curriculum 2002 and 11 objectives in 2012. ${ }^{21,22}$ Although there were some linguistic discrepancy in objectives of two curricula but essence of 10 objectives were same. Researchers sorted out curricular objectives suitable for assessing through written questions of professional examinations, and 7 objectives were selected. For convenience, researchers assigned chronological number against each objective, e.g. no. 1 objective, no. 2 objective, no. 3 objective etc. Then a list of probable questions for each curricular objective was prepared. For analysis, researchers reviewed the question paper thoroughly and identify questions reflecting specific objectives of curriculum. If present, then those questions were included and calculated for analysis. The Pharmacology written question papers (SAQ) contain total 84 marks with options, where students need to answer a maximum of 70 marks. Weightage was calculated as the number reflecting each objective out of 84 marks. 
In undergraduate pharmacology curriculum, number of course contents were 11 (General principles of pharmacology, Autonomic pharmacology, Renal \& cardiovascular pharmacology, Hematopietic pharmacology, Endocrine pharmacology, Gastrointestinal pharmacology, CNS pharmacology, Autacoids \& drugs used in inflammation, Respiratory pharmacology, Chemotherapy and Clinical pharmacology). Course content wise allocation of wightage was also evaluated. Then, reflection of health care needs of community in the question papers was assessed by calculating how much weightage was given on disease burden of Bangladesh. According to Bangladesh Health Bulletin 2019, burden of cardiovacular disease was highest (30\%), followed by communicable, maternal, perinatal and nutritional condition (26\%), other non-communicable disease (12\%), cancer (12\%), Chronic respiratory disease (10\%), injuries $(7 \%)$ and diabetes $(3 \%) .{ }^{29}$ A list of probable questions for pharmacotherapy of selective disease burdens (cardiovascular disease, chronic respiratory disease, cancer and diabetes) was prepared. Researchers reviewed the question papers thoroughly, and identified both direct and indirect questions related to pharmacotherapy of disease burdens, and weightage was calculated.

\section{Statistical analysis}

Data was compiled, presented and and analyzed using Microsoft Excel 2007, and was expressed as mean percentage (standard deviation). One Way Analysis of Variance (ANOVA) was done to determine the significance of difference between the mean percentages. Statistical analysis was performed at a $95 \%$ confidence interval and significance was determined at $p<0.05$. 


\section{RESULTS}

Total 131 SAQ papers (DU-20, CU-20, RU-20, SUST-19, USTC-16, GB-16 \& BUP20) of undergraduate pharmacology written question papers dated from January 2010 to November 2019 were analyzed. Table I showed that no. 1 objective had significant higher weightage throughout the last ten years in all universities. There were statistically significant differences in weightage of reflection of curricular objectives (No.1, 2, 4, 7 \& 8) among different universities. There was not a single question reflecting no. 9 objective in last 10 years in any university.

Table I: Objective-wise marks distribution

\begin{tabular}{|c|c|c|c|c|c|c|c|c|c|}
\hline Objective & $\begin{array}{l}\text { BUP } \\
\text { (Mean } \pm \\
\text { SD) }\end{array}$ & $\begin{array}{l}\text { CU } \\
\text { (Mean } \pm \\
\text { SD) }\end{array}$ & $\begin{array}{l}\text { DU } \\
(\text { Mean } \pm \\
\text { SD) }\end{array}$ & $\begin{array}{l}\text { GB } \\
\text { (Mean } \pm \\
\text { SD) }\end{array}$ & $\begin{array}{l}\text { RU } \\
\text { (Mean } \\
\pm \text { SD) }\end{array}$ & $\begin{array}{l}\text { SUST } \\
\text { (Mean } \\
\pm \text { SD) }\end{array}$ & $\begin{array}{l}\text { USTC } \\
\text { (Mean } \pm \\
\text { SD) }\end{array}$ & $\begin{array}{l}\text { Total } \\
\text { (Mean } \pm \\
\text { SD) }\end{array}$ & $P$ value \\
\hline №. 1 & $\begin{array}{l}82.5 \\
\pm 4.8\end{array}$ & $\begin{array}{l}80.1 \pm 5 \\
6\end{array}$ & $\begin{array}{l}85.7 \pm \\
8.6\end{array}$ & $\begin{array}{l}76.1 \pm 7 \\
3\end{array}$ & $\begin{array}{l}81.1 \\
\pm 6.7\end{array}$ & $\begin{array}{l}76.7 \\
\pm 9.0\end{array}$ & $\begin{array}{l}90.8 \pm 5 . \\
1\end{array}$ & $\begin{array}{l}81.98 \\
\pm 6.7\end{array}$ & $<0.00001$ \\
\hline No. 2 & $\begin{array}{l}14.1 \pm 5 \\
4\end{array}$ & $\begin{array}{l}15.1 \\
\pm 7.0\end{array}$ & $\begin{array}{r}13.4 \\
\pm 7.6\end{array}$ & $\begin{array}{l}13.0 \\
\pm 9.7\end{array}$ & $\begin{array}{l}14.1 \pm 5 \\
.2\end{array}$ & $\begin{array}{l}17.1 \pm 9 \\
.4\end{array}$ & $6.1 \pm 4.2$ & $\begin{array}{l}13.3 \\
\pm 6.9\end{array}$ & 0.001 \\
\hline No. 3 & $1.4 \pm 2.4$ & $3.1 \pm 4.3$ & $0.7 \pm 3.1$ & $1.7 \pm 2.2$ & $\begin{array}{l}2.7 \\
\pm 3.5\end{array}$ & $\begin{array}{l}4.2 \\
\pm 5.3\end{array}$ & $2.2 \pm 2.5$ & $2.3 \pm 3.3$ & 0.06 \\
\hline No. 4 & $1.2 \pm 1.7$ & $0.2 \pm 0.7$ & $\begin{array}{l}0.00 \pm 0 . \\
0\end{array}$ & $0.4 \pm 0.9$ & $\begin{array}{l}0.3 \pm 0 \\
7\end{array}$ & $\begin{array}{l}0.4 \pm 0 \\
9\end{array}$ & $\begin{array}{l}0.00 \pm 0 . \\
0\end{array}$ & $0.4 \pm 0.7$ & 0.003 \\
\hline No. 7 & $1.2 \pm 1.7$ & $0.2 \pm 0.9$ & $0.3 \pm 0.7$ & $1.1 \pm 1.4$ & $1.6 \pm 2$ & $\begin{array}{l}0.5 \pm 0 \\
7\end{array}$ & $0.3 \pm 1.1$ & $0.8 \pm 1.2$ & 0.004 \\
\hline №. 8 & $0.1 \pm 0.3$ & $\begin{array}{l}0.00 \pm 0 . \\
0\end{array}$ & $\begin{array}{l}0.00 \pm 0 . \\
0\end{array}$ & $0.8 \pm 1.7$ & $0.2 \pm 1$ & $\begin{array}{l}0.00 \pm 0 \\
.0\end{array}$ & $\begin{array}{l}0.00 \pm 0 . \\
0\end{array}$ & $0.4 \pm 0.5$ & 0.02 \\
\hline No. 9 & $\begin{array}{l}0.00 \pm 0 . \\
0\end{array}$ & $\begin{array}{l}0.00 \pm 0 . \\
0\end{array}$ & $\begin{array}{l}0.00 \pm 0 \\
0\end{array}$ & $\begin{array}{l}0.00 \pm 0 \\
0\end{array}$ & $\begin{array}{l}0.00 \pm 0 \\
.0\end{array}$ & $\begin{array}{l}0.00 \pm 0 \\
.0\end{array}$ & $\begin{array}{l}0.00 \pm 0 \\
0\end{array}$ & $\begin{array}{l}0.00 \pm 0 \\
0\end{array}$ & - \\
\hline
\end{tabular}

Data expressed as mean percentage (SD) and analyzed by One Way Analysis of Variance (ANOVA), $\mathrm{p}<0.05$ - Significance

*No. 1 Objective: Describe the pharmacological effects, mechanisms of action, pharmacokinetic characteristics and adverse reactions of drugs in order to be able to prescribe safely and effectively

*No. 2 Objective: Describe the basic principles and concepts considered essential for rational (effective, safe, suitable and economic) prescribing and use of medicines in clinical practice

*No. 3 Objective: Understand the principles of rational prescribing and the basis of utilizing the principles of rational evaluation of therapeutic alternatives

*No. 4 Objective: Recognize, manage and report the adverse drug reactions (ADRs) and drug interactions

*No. 7 Objective: State the Essential Drug List and principles underlying the 'Concept of Essential Drugs', and apply them in community-oriented health care delivery service

*No. 8 Objective: Recognize the implications of poly pharmacy and other means of irrational prescribing, identify influences favoring irrational prescribing and develop means to resist them

*No. 9 Objective: Evaluate the ethical and legal issues involved in drug prescribing, development, manufacture and marketing 
Table II showed there were statistically significant differences in content-wise weightage among different universities except gastrointestinal pharmacology. Chemotherapy was the highest covered area, followed by central nervous system and general principles of pharmacology throughout the last ten years in all universities (Table II). In curriculum, allocated teaching hours for chemotherapy was highest, followed by general principles of pharmacology and central nervous system (Table III).

Table II: Content-wise marks distribution

\begin{tabular}{|c|c|c|c|c|c|c|c|c|}
\hline Content & $\begin{array}{l}\text { BUP } \\
\text { (Mean } \\
\pm \text { SD) }\end{array}$ & $\begin{array}{l}\text { CU } \\
(\text { Mean } \\
\pm \text { SD) }\end{array}$ & $\begin{array}{l}\text { DU } \\
\text { (Mean } \pm \\
\text { SD) }\end{array}$ & $\begin{array}{l}\text { GB } \\
(\text { Mean } \\
\pm \text { SD) }\end{array}$ & $\begin{array}{l}\text { RU } \\
(\text { Mean } \pm \\
\text { SD) }\end{array}$ & $\begin{array}{l}\text { SUST } \\
\text { (Mean } \pm \\
\text { SD) }\end{array}$ & $\begin{array}{l}\text { USTC } \\
(\text { Mean } \pm \\
\text { SD) }\end{array}$ & P value \\
\hline $\begin{array}{l}\text { General } \\
\text { Principles }\end{array}$ & $\begin{array}{l}13.3 \pm 3 \\
1\end{array}$ & $\begin{array}{l}15.3 \pm 4 \\
.3\end{array}$ & $15.0 \pm 2.8$ & $\begin{array}{l}14.1 \pm 3 . \\
9\end{array}$ & $12.2 \pm 0.8$ & $\begin{array}{l}14.5 \pm 2.8 \\
9\end{array}$ & $15.9 \pm 4.9$ & 0.02 \\
\hline $\begin{array}{l}\text { Autonomic } \\
\text { Nervous System }\end{array}$ & $\begin{array}{l}10.2 \pm 3 \text {. } \\
1\end{array}$ & $\begin{array}{l}8.2 \pm 3 . \\
6\end{array}$ & $9.6 \pm 2.3$ & $7.3 \pm 2.7$ & $10.0 \pm 2.2$ & $10.5 \pm 3.2$ & $10.7 \pm 2.6$ & 0.01 \\
\hline CVS \& Renal & $\begin{array}{l}10.2 \pm 3 . \\
4\end{array}$ & $\begin{array}{l}13.0 \pm 3 \\
.3\end{array}$ & $11.8 \pm 3.5$ & $\begin{array}{l}10.4 \pm 1 \\
7\end{array}$ & $13.8 \pm 1.9$ & $13.4 \pm 2.8$ & $12.3 \pm 5.3$ & 0.01 \\
\hline Hematopoetic & $5.9 \pm 3.7$ & $\begin{array}{l}4.5 \pm 3 . \\
4\end{array}$ & $6.0 \pm 3.1$ & $5.9 \pm 1.6$ & $6.2 \pm 2.01$ & $3.1 \pm 2.6$ & $6.6 \pm 5.5$ & 0.02 \\
\hline Endocrine & $7.7 \pm 2.7$ & $\begin{array}{l}10.7 \pm 3 \\
.3\end{array}$ & $6.1 \pm 2.7$ & $9.3 \pm 2.9$ & $8.6 \pm 1.9$ & $8.7 \pm 2.6$ & $11.4 \pm 3.9$ & $\begin{array}{l}<0.000 \\
01\end{array}$ \\
\hline Gastrointestinal & $4.8 \pm 3.2$ & $\begin{array}{l}3.9 \pm 2 . \\
1\end{array}$ & $3.1 \pm 2.9$ & $4.1 \pm 2.2$ & $3.6 \pm 1.3$ & $3.6 \pm 1.6$ & $3.6 \pm 1.4$ & 0.4 \\
\hline $\begin{array}{l}\text { Central Nervous } \\
\text { System }\end{array}$ & $\begin{array}{l}17.1 \pm 3 \text {. } \\
5\end{array}$ & $\begin{array}{l}19.3 \pm 4 \\
.8\end{array}$ & $16.7 \pm 3.9$ & $\begin{array}{l}14.2 \pm 3 . \\
4\end{array}$ & $13.1 \pm 2.5$ & $16.2 \pm 2.5$ & $15.4 \pm 3.9$ & $\begin{array}{l}<0.000 \\
01\end{array}$ \\
\hline $\begin{array}{l}\text { Autacoids \& } \\
\text { Inflammation }\end{array}$ & $5.5 \pm 4.4$ & $\begin{array}{l}4.6 \pm 3 \\
9\end{array}$ & $6.2 \pm 3.3$ & $3.7 \pm 2.0$ & $8.6 \pm 1.2$ & $5.7 \pm 2.6$ & $3.6 \pm 3.0$ & $\begin{array}{l}<0.000 \\
01\end{array}$ \\
\hline Respiratory & $3.3 \pm 1.8$ & $\begin{array}{l}2.8 \pm 2 \\
0\end{array}$ & $2.6 \pm 2.0$ & $3.4 \pm 1.4$ & $4.3 \pm 0.4$ & $3.4 \pm 1.5$ & $2.9 \pm 1.9$ & 0.043 \\
\hline Chemotherapy & $\begin{array}{l}20.0 \pm 2 . \\
4\end{array}$ & $\begin{array}{l}16.8 \pm 4 \\
.4\end{array}$ & $20.6 \pm 3.3$ & $\begin{array}{l}24.1 \pm \\
2.1\end{array}$ & $16.1 \pm 2.7$ & $19.4 \pm 3.2$ & $19.0 \pm 5.0$ & $\begin{array}{l}<0.000 \\
01\end{array}$ \\
\hline $\begin{array}{l}\text { Clinical } \\
\text { pharmacology }\end{array}$ & $2.5 \pm 1.8$ & $1.2 \pm 1$ & $2.9 \pm 2.5$ & $\begin{array}{l}3.7 \pm \\
3.8\end{array}$ & $3.8 \pm 1.2$ & $1.8 \pm 1.8$ & $0.2 \pm 0.9$ & $\begin{array}{l}<0.000 \\
01\end{array}$ \\
\hline
\end{tabular}

Data expressed as mean (SD) and analyzed by One Way Analysis of Variance (ANOVA), p<0.05Significant 
medRxiv preprint doi: https://doi.org/10.1101/2022.02.22.22271235; this version posted February 24, 2022. The copyright holder for this preprint (which was not certified by peer review) is the author/funder, who has granted medRxiv a license to display the preprint in perpetuity.

It is made available under a CC-BY-NC-ND 4.0 International license .

Table III: Content wise marks distribution and allocated teaching hours

\begin{tabular}{lcc}
\hline Content & $\begin{array}{l}\text { Total percentage of } \\
\text { marks } \\
\text { (Mean } \pm \text { SD) }\end{array}$ & $\begin{array}{c}\text { Total allocated teaching } \\
\text { hours in lecture (hours) }\end{array}$ \\
\hline General Principles & $14.3 \pm 3.2$ & 15 \\
\hline $\begin{array}{l}\text { Autonomic Nervous } \\
\text { System }\end{array}$ & $9.5 \pm 2.8$ & 12 \\
\hline CVS \& Renal & $11.1 \pm 3.1$ & 7 \\
\hline Hematopoetic & $5.5 \pm 3.1$ & 9 \\
\hline Endocrine & $8.9 \pm 2.9$ & 7 \\
\hline Gastrointestinal & $3.8 \pm 2.1$ & 14 \\
\hline CNS & $16.0 \pm 3.4$ & 5 \\
\hline $\begin{array}{l}\text { Autacoids \& } \\
\text { Inflammation }\end{array}$ & $5.4 \pm 2.9$ & $\begin{array}{c}\text { May be covered with } \\
\text { Autonomic Nervous } \\
\text { System) }\end{array}$ \\
\hline Respiratory & $3.2 \pm 1.6$ & 17 \\
\hline Chemotherapy & & 6 \\
\hline $\begin{array}{l}\text { Clinical } \\
\text { pharmacology }\end{array}$ & $19.4 \pm 3.3$ & \\
\hline
\end{tabular}

Table IV showed there was a statistically significant difference in weightage of reflection of cardiovascular disease burden among different universities.

Table IV: Disease burden wise marks distribution

\begin{tabular}{|c|c|c|c|c|c|c|c|c|c|}
\hline Disease burden & $\begin{array}{l}\text { BUP } \\
(M e a n \\
\pm \text { SD) }\end{array}$ & $\begin{array}{l}\text { CU } \\
(M \text { ean } \\
\pm \text { SD) }\end{array}$ & $\begin{array}{l}\text { DU } \\
(\text { Mean } \\
\pm \text { SD) }\end{array}$ & $\begin{array}{l}\text { GB } \\
(M e a n \\
\pm \text { SD })\end{array}$ & $\begin{array}{l}\text { RU } \\
(M e a n \\
\pm \text { SD) }\end{array}$ & $\begin{array}{l}\text { SUST } \\
(\text { Mean } \pm \\
\text { SD) }\end{array}$ & $\begin{array}{l}\text { USTC } \\
(\text { Mean } \pm \\
\text { SD) }\end{array}$ & $\begin{array}{l}\text { Total } \\
(\text { Mean } \pm \\
\text { SD) }\end{array}$ & P value \\
\hline $\begin{array}{l}\text { Cardiovascular } \\
(30 \%)\end{array}$ & $\begin{array}{l}15.8 \pm 3 . \\
2\end{array}$ & $\begin{array}{l}16.1 \pm \\
3.9\end{array}$ & $\begin{array}{l}19.6 \pm 5 . \\
0\end{array}$ & $\begin{array}{l}14.3 \pm 3 \\
8\end{array}$ & $\begin{array}{l}20.5 \pm 3 . \\
8\end{array}$ & $18.4 \pm 3.9$ & $19.5 \pm 5.3$ & $17.7 \pm 4.1$ & $<0.00001$ \\
\hline Cancer $(12 \%)$ & $0.2 \pm 1.0$ & $\begin{array}{l}0.0 \pm 0 \\
0\end{array}$ & $0.4 \pm 1.1$ & $0.0 \pm 0.0$ & $0.5 \pm 1.2$ & $0.0 \pm 0.0$ & $0.0 \pm 0.0$ & $0.5 \pm 0.5$ & 0.3 \\
\hline $\begin{array}{l}\text { Chronic } \\
\text { respiratory } \\
\text { disease }(10 \%)\end{array}$ & $3.2 \pm 1.9$ & $\begin{array}{l}3.1 \pm 2 . \\
0\end{array}$ & $2.7 \pm 2.4$ & $3.8 \pm 2.2$ & $4.3 \pm 0.4$ & $4.1 \pm 1.9$ & $3.5 \pm 1.8$ & $3.5 \pm 1.8$ & 0.2 \\
\hline Diabetes $(3 \%)$ & $3.8 \pm 1.9$ & $\begin{array}{l}4.0 \pm 1 \\
2\end{array}$ & $3.3 \pm 3.2$ & $4.5 \pm 1.6$ & $4.0 \pm 1.5$ & $3.8 \pm 2.0$ & $5.3 \pm 2.7$ & $4.1 \pm 2.0$ & 0.5 \\
\hline
\end{tabular}

Data expressed as mean (SD) and analyzed by One Way Analysis of Variance (ANOVA), $\mathrm{p}<0.05-$ Significant 


\section{DISCUSSION}

Re-addressing assessment methods is a crucial step for transformation of medical education and over the years, innovative measures are taken for provision of accurate and timely assessment of future physicians. ${ }^{30}$ Current study was conducted to analyze and compare pharmacology question papers of different universities of Bangladesh in respect to reflection of curricular objectives, content coverage and selective disease burdens for last 10 years.

Objectives are statements that describe the end-points or desired outcome of the curriculum which guide the assessment method, outline content and instructional materials, contribute towards achieving the intended educational outcomes, shaping expectations, prepare learners for the educational activity and the standard by which their performance will be measured. ${ }^{31}$ No. 1 objective had significant higher weightage throughout the last ten years in all universities, followed by no. 2 and no. 3 objective. No. 1 objective actually presents knowledge and comprehension, whether no. 2 and no. 3 objectives demonstrate application, analysis and evaluation. Higher proportion of coverage of factual knowledge in professional exam question papers of pharmacology was also revealed in studies conducted in Bangladesh and India. ${ }^{24,26,28,}$ 32, 33 Important issues of prescribing like adverse drug reactions, essential medicines, rational prescribing, ethical and legal aspects are still neglected in undergraduate pharmacology education, and this finding is concordance with previous literatures. ${ }^{23,}$ ${ }^{27}$ It is assumed that it's convenient for question setters and moderators to prepare questions in traditional way as they are probably not adequately trained in adaptation of changing aspects of pharmacology teaching-learning. ${ }^{34}$ Current study also found statistically significant difference of weightage in reflection of curricular objectives 
(No.1, 2, 4, 7 \& 8) among different universities, and there was no available research to compare the findings.

In case of content coverage, it was found that Chemotherapy, CNS pharmacology, General principles of pharmacology, Renal \& cardiovascular pharmacology and Autonomic pharmacology were the maximum weightage of content area, and the findings were similar to related studies conducted in Bangladesh. ${ }^{26,}{ }^{28}$ Increased weightage on Hematopietic pharmacology was observed in current study that was similar to Begum et $\mathrm{al}^{24}$ but contrary to two recent studies. ${ }^{26,28}$ Weightage on Endocrine pharmacology was consistent with related studies. ${ }^{23}, 24,26,28$ There was statistically significant difference among different universities in weightage of all content areas except Gastrointestinal pharmacology, and no comparable study was found to correlate this finding. There were some discrepancies in weightage of different contents with their allocated teaching hours, and that was concordance with an earlier study conducted in Bangladesh. ${ }^{23}$ A test blueprint and question bank would be helpful for the question setters and moderators for adequate content coverage. ${ }^{28,35}$

Current study compared reflection of selective disease burdens in written question papers and found statistically significant difference (p value <0.00001) in cardiovascular diseases among different universities. Although there was no comparable study, earlier researches concluded less emphasis on national health priorities in pharmacology question papers of Bangladesh. ${ }^{23,}{ }^{24}$ One recent study conducted in Bangladesh revealed pharmacology written question papers of different universities under guidance of same curriculum of BMDC differ in the aspect of weightage of problem-based questions. ${ }^{36}$ 


\section{CONCLUSION}

Current study revealed variation in undergraduate pharmacology written question papers of different universities in the aspects of reflection of curricular objectives, content coverage and cardiovascular disease burden. A clear direction of weightage of each objective, contents and disease burdens are needed to mention in the undergraduate curriculum. As assessment drives learning priority, it's crucial for question setters and moderators to maintain uniformity of written question papers of different universities following same curriculum of BMDC. 


\section{REFERENCE}

1. Engels F. Pharmacology education: Reflection and challenges. European Journal of Pharmacology. 2018; 833: 392-95.

2. Dikshit RK. Rational education for rational therapy. World Health Forum. 1992; 13: 151-3.

3. Dornan T, Ashcroft D, Heathfield H, Lewis P, Miles J, Taylor D, Tully M, Wass V. An in-depth investigation into causes of prescribing errors by foundation trainees in relation to their medical education: EQUIP study. Final report to the General Medical Council. University of Manchester: School of Pharmacy and Pharmaceutical Sciences and School of Medicine. 2009. Available at http://www.gmc-uk.org/FINAL_ Report_prevalence_and_causes_of_prescribing_errors.pdf_28935150.pdf [Accessed on 31.10.2021]

4. Ross S, Ryan C, Duncan EM, Francis JJ, Johnston M, Ker J, et al. Perceived causes of prescribing errors by junior doctors in hospital in-patients: a study from the PROTECT programme. BMJ Qual Saf 2013; 22: 97-102.

5. McLellan L, Tully MP, Dornan T. How could undergraduate education prepare new graduates to be safer prescribers? Br J Clin Pharmacol 2012; 74: 605-13.

6. Illing J, Morrow G, Kergon C, Burford B, Spencer J, Peile E, et al. How prepared are medical graduates to begin practice? A comparison of three diverse UK medical schools. Final report to GMC April 2008.

7. Miles S, Kellett J, Leinster SJ. Medical graduates' preparedness to practice: a comparison of undergraduate medical school training. BMC Med Educ 2017; 17(1):33. doi: 10.1186/s12909-017-0859-6

8. Heaton A, Webb DJ, Maxwell SR. Undergraduate preparation for prescribing: the views of 2413 UK medical students and recent graduates. Br J Clin Pharmacol 2008; 66 (1): 128-34.

9. Harden RM. AMEE Guide No. 21: Curriculum mapping: a tool for transparent and authentic teaching and learning. Medical Teacher. 2001;23:123-137

10. Prideaux D. ABC of learning and teaching in medicine curriculum design. British Medical Journal. 2003; 326; 268-70.

11. Hooper L, Begg MD, Sullivan LM. Integrating competencies and learning outcomes in core courses for the MPH. Public Health Rep 2014;129:376-381.

12. Friedman Ben-David M. The role of assessment in expanding professional horizons. Med Teach 2000;22:472-7

13. Sullivan W. Work and integrity: the crisis and promise of professionalism in America. 2nd ed. San Francisco: JosseyBass, 2005.

14. Epstein RM. Assessment in medical education. N Engl J Med 2007; 356 (4):387-96.

15. Hayes K. Written assessment. In: Walsh K, ed. Oxford Textbook of Medical Education. Oxford University Press, 2013.

16. Sood R. Assessment in medical education: Trends and tools. All India Institute of Medical Science, New Delhi, India, I995.

17. Cunningham GK. Assessment in the classroom: Constructing and interpreting tests. Falmer Press, London, 1998

18. Feletti GI, Smith EK. Modified Essay Questions: Are they worth the effort? Medical Education, 1986 ; 20 (2):126-132

19. Ellingon H. Short answer questions. In: Teaching and learning in higher education. Scottish Central Institutions Committee Educational development. Aberdeen, UK, 1987 
20. Faiz MA. Medical education in Bangladesh- Is there room for improvement? JCMCTA. 2007; 18: 1-3.

21. Bangladesh Medical \& Dental Council (BMDC). Curriculum for Undergraduate Medical Education in Bangladesh - updated 2002. Bangladesh Medical \& Dental Council (BMDC), 2002, Dhaka, Bangladesh. Available at: http://bmdc.org.bd/mbbs-curriculum-update-2002/ [Accessed on 02/11/2021]

22. Bangladesh Medical \& Dental Council (BMDC). Curriculum for Undergraduate Medical Education in Bangladesh - updated 2012. Bangladesh Medical \& Dental Council (BMDC), 2012, Dhaka, Bangladesh. Available at: http://bmdc.org.bd/mbbs-curriculum-update-2012/[Accessed on 02/11/2021]

23. Begum M, Rahman MS, Islam AFMS, Khan IA, Akhter N. Eleven Years of the Undergraduate Medical Curriculum 1988: review on the changes in Pharmacology written questions. Bangladesh J Physiol Pharmacol. 1999; 15: 27-30.

24. Karim A, Haque M. 1996. Assessment system in Pharmacology- Does it Reflect Educational objectives and Community Health Needs? Bangladesh J Physiol Pharmacol. 1996; 12: 65-67.

25. MS Rahman, S Huda. Antimicrobial resistance and related issues: An overview of Bangladesh situation. Bangladesh Journal of Pharmacology. 2014; 9, 218-224.

26. Chowdhury DK, Saha D, Talukder MH, Habib MA, Islam A, Ahmad MR, Hossin MI. Evaluation of Pharmacology Written Question Papers of MBBS Professional Examinations. Bangladesh Journal of Medical Education. 2017; 8: 12-17.

27. Johora F, Rahman MS. Pharmacology education in the perspectve of pharmaceutical promotion: Bangladesh experience. Bangabandhu Sheikh Mujib Med Univ J 2019; 12: 128-132.

28. Nahar N, Kutubi A, Khan TH, Banu LA, Jahan I, Badhon NM. Analysis of undergraduate pharmacology written question of different universities I Bangladesh. J Shaheed Suhrawardy Med Coll 2017: 9 (1) 13-17.

29. Directorate General of health Services (DGHS). Bangladesh Health Bulletin 2019. DGHS, Dhaka, Bangladesh. Available at:https://dghs.gov.bd/images/docs/Publicaations/Health\%20Bulletin\%202019\%20Print\%20Version\%20(2)-

Final.pdf [Accessed on 02/11/2020]

30. Leung WC. (2002). Competence based medical training: review. BMJ 325:693-6.

31. Swanwick T, McKimm J. Setting learning objectives. British Journal of Hospital Medicine. 2009; 70: 406-09.

32. Saj NP. Comprehensive analysis of theory exam question papers of $2^{\text {nd }}$ MBBS pharmacology subject in Rajiv Gandhi University of Health Sciences, Karnataka, India. International Journal of Basic \& Clinical Pharmacology. 2019; 8 (8): 1739-99.

33. Sindhu S, Singh HK, Saiman MT, Verma, VK. Comparative Evaluation of Pharmacology Question Papers in Medical Colleges Affiliated to Different universities in North India along with recommendations. Journal of Research in Medical Education \& Ethics. 2011;1 (3): 180-86.

34. Rahman MS. Changes required in pharmacotherapy teaching to ensure rational use of drugs (letter to the editor). Bangladesh J Physiol Pharmacol. 1995; 11: 38-39.

35. Raymond MR, Grande JP. A practical guide to test blueprinting. Medical Teacher 2019; 41(8):854-861

36. Johora F, Abbasy AA, Mahboob S, Jeenia FT, Ferdoush J, Rahman MS. Trend and Weightage of Problembased Questions in Undergraduate Pharmacology Written Question Papers of Bangladesh. medRxiv 2021. 02.02.22270345. doi: https://doi.org/10.1101/2022.02.02.22270345 